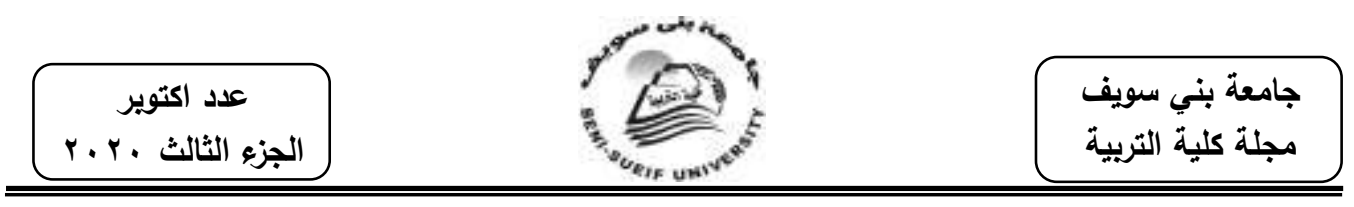

\title{
Using active learning strategies to improve preparatory \\ Stage pupils' speaking skills
}

$$
\text { By }
$$

Rehab Mohamed Farghaly

Teacher of English

Supervised by

Dr.Heba Mustafa Muhamed

Prof. of Curriculum and

Instruction (TEFL),BeniSuief B

University and Head of the department
Dr. Hayat Refaey Ali

\section{Abstract}

The present study was conducted to investigate using active learning strategies on developing speaking skills of $3^{\text {th }}$ year pupils at prep school. A pre-post non-treatment group research design was used to achieve the research objectives. Fifty pupils were randomly divided into two groups: the treatment and the treatment groups. The treatment group pupils were trained through activities based on active learning strategies. The non-treatment used was based on the content of the student's book. The non-treatment group pupils were taught the same content through the conventional method of teaching. The sub skills of speaking that were most needed to the participants and to the difficulties they faced when studying the speaking skills, pre-post tests in speaking. Analysis of data obtained by students (using t-test) revealed that the experimental group significantly surpassed the control one on the post performance. Discussion of these results, recommendations and suggestions for further research are presented.

Key words: Active Learning Strategies_speaking skills 


\section{Introduction}

Language features a extraordinary significance in lifestyle. Language makes a difference to individuals, thoughts, feelings and suppositions.It may be a fundamental means of communication utilizing sounds, signals, signs or images. It recognizes people from all other living beings. Over the a long time, English language got to be the essential dialect all over the world. It got to be the universal means of communication. It is the foremost commonly used language. When individuals from diverse nations need to communicate, they utilize English language. It appears that most individuals crave to memorize English. Listening and speaking are a portion of communication in day by day life.

Windle and Warren(201',p.11)Language is one of the important factors which help communication between people. People depend on effective communication with others in our daily life to exchange ideas, understand others, and solve problems... etc. (Morozova,2013,p:1) It is observed that English displaced other languages and holds a basic role as an important means of communication worldwide. Everyone tries to get the benefits of modern education, research, trade, science, etc; to achieve this target,he/ she should have a working knowledge of the English language and a working knowledge of the good communication skills. Lacking communication skills causes difficulty for people to achieve their goals in this modern world of media, mass communication and internet that needs good knowledge of English, especially of spoken English.

As a teacher of EFL, the researcher noticed that speaking skills of EFL are obviously not taken care of. Teachers need help to gain ways by which they increase their ability to help preparatory school students to speak EFL fluently and understand comprehensively when they speak to it as well. Speaking is considered one of the four basic skills necessary to communicate effectively in any language, especially when the speaker doesn't use his mother tongue. It plays an important role in achieving communication among people. Because of the importance of English, we should develop speaking skills to achieve successful communication with the native speakers of English and non-native 
speakers in any community (Boonkit, 2010,p.1306). Speaking skills are related to the other skills. Students use speaking to express their ideas, understand clearly, discuss what they read, improve their confidence when they speak in front of others, produce good writing after talking, and to encourage themselves to think by talking (Smith, 2013,p.3).

Speaking is considered an important part of the process of language learning. When speaking is used as a means of effective communication, it provides many benefits for the speakers, for example, job interviews, job training activities, and many other business purposes (Osborn, 2018 cited in Boonkit, 2020,p.1306). When teachers teach their students to speak students can use their ability of speaking to learn. Many language learners assess their progress according to their success in spoken communication (Bahrani, 2012,P.p.25-27).

\section{The Speaking Skills were}

- Producing sounds.

- Using core vocabulary.

- Using short statements, questions and commands.

- Using the basic intonation patterns in questions answers.

\section{Context of the Problem}

Pupils of 3third year preparatory school were unable to speak correctly. However, they got intimidated, pressured by time or fellow pupils. They tended to use their mother tongue, if they did not know a single word or were interrupted and refused to continue speaking.

The researcher observed that the pupils talking time was uneven, some pupils speak a lot while others remained unable to speak. The pupils lacked the necessary skills for communication in the target language. It was also observed that the traditional methods of teaching speaking were ineffective, so the researcher thought that using active learning strategies that hopefully might improve the pupils' speaking skills.

\section{Amis of the Study}

The aims of this study are:

- To identify the effectiveness of using active learning strategies based for developing $3^{\text {th }}$ year preparatory stage pupils' speaking skills. 
Hypothesis of the Study

There is a statistically significant differences favoring the treatment group between means of scores obtained by the treatment and non-treatment groups on the post test of speaking skills.

\section{Question of the Study}

The question of the study is

- What is the effectiveness of using active learning strategies for developing $3^{\text {th }}$ year preparatory stage pupils' speaking skills?

\section{Significance of the Study}

\section{- Contributions for pupils'}

1. Active Learning Strategies provides pupils with suitable activities for developing their speaking skills.

2. Active Learning Strategies offers them a comfortable and relaxing atmosphere for learning EFL.

3. It would focus on the pupils' centered classroom.

\section{B. Contributions for primary school Teachers}

1. Active Learning Strategies help preparatory school EFL teachers adopt new roles such as facilitators and guides.

2. The study provides teachers with sample exams to evaluate speaking skills.

\section{Delimitations of the Study}

1. The activities based on active learning strategies were delimited to:

- Observation

- Creation and invention

$\circ$ Interpretation

o Word-play

○ Problem solving

- Introductory exercises

- Games

2. Fifty pupils' in rolled in $3^{\text {th }}$ graders at Al Hadesa School for Basic Education School were randomly drawn to participate in the study.

3. The speaking sub skills were limited to: 


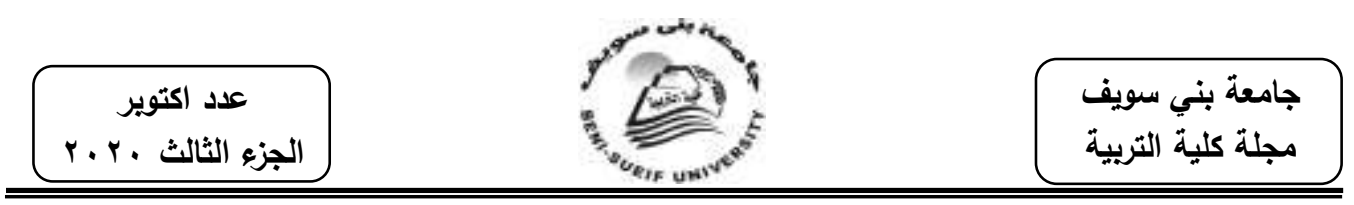

\section{A. Speaking skills}

- Producing sounds clearly.

- Expressing grammatical relationships in spoken utterances at the sentence level.

- Producing chunks of language of different length.

\section{Definitions of Terms}

- Using vocabulary appropriately.

\section{Active Learning}

Fink (2009) mentions that many teachers today want to move from past passive learning to active learning, teachers seek better ways of engaging students in the learning process but many of teachers feel a need for help in imagining what to do in class in order to constitute a meaningful set of active learning activities.

Active learning is manifested when children discover learning(Firlik,2012,p.43) the role of the teacher as lecture is less. Instead, the teacher directs the students to discover the material as pupils work with other pupils. The goal is to bring students into the process of their own education.

Active learning could also overcome the individualistic and competitive nature of traditional education (Iorenzo,2013,p.33)

\section{Speaking Skills}

Baily (2012) defined the speaking skill as the productive oral skill. It consists of producing systematic verbal utterances to convey meaning.

"Speaking is defined as the secondary stage students' ability to express themselves orally, coherently, fluently and appropriately in a given meaningful context to serve both transactional and interactional purposed using correct pronunciation, grammar and vocabulary and adopting the pragmatic and discourse rules of the spoken language. (Torky,2016,p.30).

Abbott and Godinho (2011,p.67) mention that oral communication is central to all key learning areas. Despite acknowledgment of the importance of oral communication, the development of basic skills is frequently overlooked, because of the priority given to the written mode and the overcrowded curriculum. 
David and Alexander (2011,p.88) note that educators have long organized the need for improving students oral communication abilities and performance.

\section{Studies related to using active learning strategies in Teaching English}

Boyle (2010) outlines principles relevant to active learning such as authentic tasks, attention to interaction, and negotiation of meaning. Learners construct knowledge through negotiation and discussion as this allow them have voice and ownership in the learning process.

Bulter (2011) combined two previously described active learning instructional strategies (i.e., minute papers with-think-pair-share) by having students write short responses to instructor-posed contentrelated questions on index cards and then discuss their responses in groups of 2-3. This activity motivated increased attendance and was well received by students.

Austin and Mes-cia (2014), asserts that active learning methodologies are generally more preferable than passive learning approaches.

Prince's (2014,p.17) review concluded, "Although the results vary in strength, every form of active learning examined proved beneficed".

Haithm (2012) asserts the importance of using active learning strategies such as problem solving discussion and brain storming as they depend mainly on the learner.

\section{Studies related to speaking skills}

Folse and Ivone (2015) pointed out that some students are naturally good at speaking and they tend to participate in all conversations and oral exercises while others can be quite and reserved.

Regarding speaking skills, Huntly (2016) pointed out that "the classes remain mostly teacher fronted and few pairs or groups activities are taking place

Wei (2018) found that students' speaking participation is increased if application and presentation activities are used; appropriate vocabulary is offered when students need it to continue; questions related to students' prior experience are asked; and an informal and friendly classroom is present. 
عدد اكتوبر

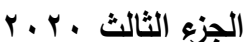

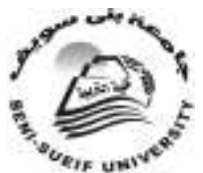

جامعة بني سويف كإنة لتربية

مجلة كلية التربية

Methodology

The treatment design

The present study followed a quasi-treatment pre-post test design. Two groups were exposed to pre-post testing. The treatment group was taught through using the active learning strategies-based activities whereas the non-treatment group received no such treatment.

\section{Instructor}

The treatment group was instructed by the researcher herself and acted as a facilitator and a guide for that group. She also taught the non-treatment group according to the conventional way of teaching.

\section{Participants of the study}

Fifty pupils were involved in the study. They were divided in two groups the treatment group " 25 " and the non-treatment group " 25 ". The participants of the study were chosen from "Al Hadesa for Basic Education School". They were chosen from one school to achieve homogeneity among participants.

\section{Variables of the study}

- The independent variable

Using strategies of active learning in teaching EFL.

- The dependent variables

$3^{\text {th }}$ year pupils' speaking skills.

- The controlled variables

To ensure homogeneity among the pupils of the two groups the following variables were controlled:

1. Years of studying English.

2. Age.

3. Institute of education: All participants were in sixth year preparatory school.

4. The level of performance on the pre-speaking test.

General Objectives of the activities based on active learning strategies

The activities based on active learning strategies aimed at developing some speaking skills of $3^{\text {th }}$ graders learning English as a foreign language (EFL). 
- producing sounds clearly.

- expressing grammatical relationships in spoken utterances at the sentence level.

- producing chunks of language of different length.

- using vocabulary appropriately.

Constructing the active learning strategies went through the following steps

- Reviewing the related literature

- Using a list of the speaking skills already developed to state the general objectives of the active learning strategies

- Judging the whole active learning strategies by the same jury members for its content and general form to approve its validity and suitability for the students and for the objectives of the study

Main features of the active learning strategies are

- The speaking skills were represented in terms of the given content and presented through the general and behavioral objectives of the active learning strategy.

- Presentation techniques used were: observation, creation and invention, interpretation, word-play, problem solving, introductory exercises.

- Teaching aids included audio materials, real objects, pictures, cards, wall paper, and paper box.

- Formative evaluation came at the end of each lesson to provide an immediate feedback.

- "Home fun" was provided at the end of each lesson.

- A revision lesson was provided at the end of each unit.

\section{The Speaking pre-post Test}

\section{A. Objectives}

The speaking test was designed for $3^{\text {th }}$ graders. Pupils achieved the following objectives

- Producing sounds clearly.

- Expressing grammatical relationships in spoken utterances at the level of sentence. 
عدد اكتوبر

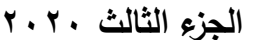

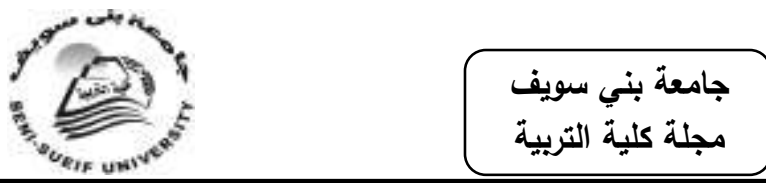

- Producing chunks of language of different length (statements, questions, commands........)

- Using vocabulary appropriately.

\section{B. Construction}

- The researcher reviewed literature on oral language assessment

- The speaking test included 3questions and each has a number of items.

- The items within the "Speaking test" were divided to3questions: The examiner explained the task using the examinee's mother tongue.

- A panel of EFL and TEFL experts examined the test in the light of the table of specifications and decided that the test is suitable to be conducted on the chosen participants. Their comments were taken into consideration.

\section{Content Validity}

The test was validated by a panel of TEFL expert to determine its validity.

\section{Item Analysis}

- Index of difficulty.

- Index of discrimination.

Table(1) reveals that indices of difficulty of the speaking test item range from (0.40 to 0.60$)$ which means that test includes varied items to match the different levels of pupils. Thus the difficulty level of the test is acceptable. The table also reveals also that the items of the test can positively discriminate between high achievers and low achievers. The power of discrimination ranges from $(0.41$ toz0.55).

\section{Table (1)}

Index of Difficulty and Index of Discrimination of the Speaking Test

\begin{tabular}{c|l|l|c|l|l}
\hline Item & Diff. & Dis. & Item & Diff. & Dis. \\
\hline 1. & 0.50 & 0.45 & 14 & 0.70 & 0.42 \\
\hline 2. & 0.60 & 043 & 15 & 0.55 & 0.44 \\
\hline 3. & 0.69 & 0.44 & 16 & 0.66 & 0.54 \\
\hline 4. & 0.57 & 0.55 & 17 & 0.68 & 0.43 \\
\hline 5. & 0.56 & 0.55 & 18 & 0.66 & 0.54 \\
\hline 6. & 0.65 & 0.44 & 19 & 0.77 & 0.45 \\
\hline 7. & 0.55 & 0.46 & 20 & 0.55 & 0.43 \\
\hline
\end{tabular}




\begin{tabular}{|c|c|c|c|c|c|}
\hline 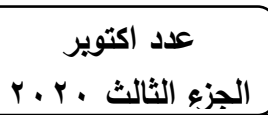 & & & & & جامعة بنية سويف التربية \\
\hline Item & Diff. & Dis. & Item & Diff. & Dis. \\
\hline 8. & 0.77 & 0.44 & 21 & 0.54 & 0.45 \\
\hline 9. & 0.67 & 0.54 & 22 & 0.66 & 0.44 \\
\hline 10. & 0.62 & 0.54 & 23 & 0.56 & 0.55 \\
\hline 11. & 0.60 & 0.54 & 24 & 0.58 & 0.65 \\
\hline 12. & 0.60 & 0.44 & 25 & 0.53 & 0.44 \\
\hline 13. & 0.60 & 0.44 & 26 & & \\
\hline
\end{tabular}

\section{Scoring the test}

Pupil's answers were recorded during the test. The researcher was the first rater who assigned marks to pupils' answers on the Speaking Test. Another colleague with the same qualifications of the researcher was the second rater who assigned marks to the pupils after listening to their recorded answers. Table (2) shows that there was high and significant correlation between those assigned by the first rater and the second rater. Each question had to be marked according to the speaking rubric. The rater has to assign a mark for each question based on the indicators and the benchmarks that range from 1 to 4 according to the level of pupil's performance during the speaking test.

\section{Instructions of the Test}

Instructions of the test were written in English using clear simple words to be easily understood by the pupils and to avoid any ambiguity. They include the objectives of the test and time allowed to answer the questions.

\section{Internal Consistency of The Speaking Test}

To establish the validity of the speaking test, correlation coefficient between each item and the whole test were calculated. They ranged from $(0.70$ to 0.91$)$. This coefficient has a statistical significance that improves the reliability of the speaking test.

Table (2)

Correlation Coefficients between each item and the Rest of the Questions

\begin{tabular}{l|l}
\hline Question Number & Pearson Correlation \\
\hline Question 1 & 0.91 \\
\hline Question 2 & 0.78 \\
\hline Question 3 & 0.78 \\
\hline Reliability
\end{tabular}

\section{Test Reliability}

The researcher used test re-test method to calculate the reliability of the test. The test was conduced on 30 pupils and then re-applied after 
two weeks. The correlation coefficient between the first implementation of the test and the second one (re-test) is shown in Table (3).

\section{Table (3)}

The Correlation Coefficient Between the Test and Re-test of the Speaking test

\begin{tabular}{l|l|l|l|l|l}
\hline $\begin{array}{l}\text { Question } \\
\text { Number }\end{array}$ & Means & $\begin{array}{l}\text { Standard } \\
\text { Deviation }\end{array}$ & Means & $\begin{array}{l}\text { Standard } \\
\text { Deviation }\end{array}$ & $\begin{array}{l}\text { Pearson } \\
\text { Correlation }\end{array}$ \\
\hline Question 1 & $\mathbf{9 . 4 4}$ & $\mathbf{3 . 6 1}$ & 9.25 & $\mathbf{3 . 6 0}$ & $\mathbf{0 . 9 4}$ \\
\hline Question 2 & $\mathbf{8 . 1 6}$ & $\mathbf{3 . 0 5}$ & $\mathbf{8 . 4 8}$ & $\mathbf{3 . 0 2}$ & $\mathbf{0 . 9 5}$ \\
\hline Question 3 & $\mathbf{6 . 5 0}$ & $\mathbf{2 . 6 0}$ & $\mathbf{7 . 0 5}$ & $\mathbf{2 . 4 5}$ & $\mathbf{0 . 9 3}$ \\
\hline Total & $\mathbf{2 4 . 1}$ & $\mathbf{9 . 2 6}$ & $\mathbf{2 4 . 7 8}$ & $\mathbf{9 . 0 7}$ & $\mathbf{2 . 8 2}$ \\
\hline
\end{tabular}

**Correlation is significant at the 0.01 level Maximum Score $=50$

Table(3) reveals that the coefficient correlation ranged from $(0.93$ to $0.95)$ and the correlation coefficient of the total mark was $(0.93)$ which is considered to have a statistical significance. 


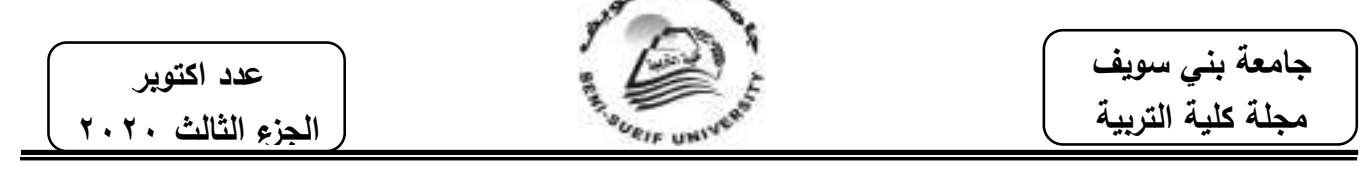

\section{Table (4)}

Correlation Coefficients Between the First Rater and the Second Rater in Marking the Speaking Test

\begin{tabular}{l|l|l|l|l|l}
\hline $\begin{array}{l}\text { Question } \\
\text { Number }\end{array}$ & First Rater & & Second Rater & $\begin{array}{l}\text { Pearson } \\
\text { Correlation }\end{array}$ \\
\hline & Means & $\begin{array}{l}\text { Standard } \\
\text { Deviation }\end{array}$ & Means & $\begin{array}{l}\text { Standard } \\
\text { Deviation }\end{array}$ & \\
\hline Question 1 & 9.41 & 3.53 & 8.99 & 3.44 & 0.95 \\
\hline Question 2 & 8.33 & 4.02 & 8.32 & 3.03 & 0.93 \\
\hline Question 3 & 7.55 & 3.01 & 7.12 & 2.45 & 0.97 \\
\hline Total & 25.29 & 10.56 & 24.43 & 8.92 & 2.85 \\
\hline
\end{tabular}

** Significant at 0.01

The Control Variables

To achieve homogeneity and equality of the two groups, the researcher controlled the following variables:

\section{Pre- Testing}

To achieve the homogeneity and equivalence of the treatment and control groups, the following variables were controlled

\section{A. Speaking Test :}

The speaking pre-test was conducted 15 days before the real administration of the active learning. The speaking test was implemented on the treatment and the non-treatment groups. The results of the pre testing showed that both groups had almost the same level of performance. The table below reveals the means of scores, standard deviations and the " $t$ " value obtained by both groups.

\section{Table (5)}

Means, Standard of Deviation and 't-Values' of Pupils' results of both treatment and the non-treatment Groups of the Pre-Testing of the Speaking Skills

\begin{tabular}{l|l|l|l|l|l|l}
\hline Pupils & Tre.Group & $\mathbf{1 = 2 5})$ & Non tre.Group & $(\mathbf{n = 2 5})$ & D.F & t-Value \\
\hline \multirow{5}{*}{50} & Means & SD & Means & SD & & \\
\cline { 2 - 6 } & 28.32 & 4.85 & 27.56 & 7.17 & 48 & 0.44 \\
\hline
\end{tabular}

Based on the data in the above table, there was no significant difference between means of scores obtained by participants of the treatment and the non-treatment groups on the pre-testing of the speaking skills. 
عدد اكتوير

\section{Years of Studying English}

Participants in both groups studied English for eight years since the final year preparatory school.

\section{Age}

The age of eight year preparatory school pupils ranged from 14 to 15 years old with almost the same number in each group.

\section{Procedures of Teaching the non-treatment Group}

While teaching the non-treatment group, the researcher went through the following procedures

- Beginning the class with greeting pupils and checking the absentees. Beginning with a funny warm up to attract pupils' attention

- Declaring the objectives of the session and what would be done throughout.

- Storming pupils' minds by asking them to look at the picture of the lesson and say what they expect the lesson or the unit would be about.

- Presenting the new vocabulary items through learning circles pupils themselves reached the meaning of new items by guessing or building upon the teacher's examples given in simple English.

- Inductive explanation of the new grammatical structure was used, and then practiced through playing roles in active learning strategy (dramatic) situations.

- Speaking activities were varied and students had to use English language most of the time.

- During the class, pupils determined rules of the class as a step of classroom management.

- Time was divided upon parts of the lesson. Each part had a limited period of time.

- Using different teaching aids to suit all pupils.

- Using interesting rewarding techniques (magical coins, jewels....). 


\section{Procedures of the study}

- Reviewing the related literature active learning strategies, speaking skills.

- Stating the general and the behavioral objectives of the program.

- Designing the frame of the active learning strategies program.

- Judging the frame.

- Establishing the validity of the active learning strategies by a panel of jury members.

- Constructing the instruments and having them validated by EFL experts (Speaking test).

- Establishing the reliability and the validity of the instruments.

- Equating the treatment and the non-treatment groups in the control variables (age and language proficiency level).

- Pre-testing both the treatment and the non-treatment groups.

- Implementing the active learning strategies on the treatment group in the English classes.

- Post testing both groups using the same procedures followed in the pre-testing stage.

- Using the appropriate statistical methods of analyzing the obtained data.

\section{Results}

Quantitative methods were employed to determine the differences in communicative speaking sub skills between the treatment and the control groups on the pre-post tests. It was predicted that there would be a significant statistical difference favoring the treatment group between mean scores obtained by the pupils of the treatment and the non-treatment groups in the post-performances on the test of speaking sub-skills. Analysis of the collected data using 't-test' showed that the obtained 't-value' (5.52) is significant 0.05 level.

Hence the second hypothesis is accepted. Table (5) shows a summary of the analyzed data obtained in the post-performance of the speaking test. 


\section{Table (5)}

t-value, Degree of freedom and significance of the postperformances of the treatment and the non-treatment group on the post Speaking $\operatorname{Test}(n=25)$

\begin{tabular}{|c|c|c|c|c|c|c|c|}
\hline Test & $\begin{array}{l}\text { Total } \\
\text { score }\end{array}$ & & Tre. Group & & $\begin{array}{c}\text { Non-tre } \\
\text { Group }\end{array}$ & DF & t-value \\
\hline \multirow[b]{2}{*}{ Speaking } & \multirow[b]{2}{*}{50} & Means & $\begin{array}{l}\text { Standard } \\
\text { Deviation }\end{array}$ & Means & $\begin{array}{l}\text { Standard } \\
\text { Deviation }\end{array}$ & \multirow[b]{2}{*}{48} & \multirow[b]{2}{*}{5.52} \\
\hline & & 21.08 & 2.76 & 14.91 & 4.78 & & \\
\hline
\end{tabular}

*Significant at 0.05 level

The statistical analysis in the previous table indicates that the pupils of the treatment group surpassed their counterparts on post speaking test.

\section{Table (6)}

t-value of scores obtained on the pre-post performances of the treatment group in the speaking test

\begin{tabular}{c|c|c|c|c|c|c}
\hline $\begin{array}{c}\text { Total } \\
\text { score }\end{array}$ & Pre & Post & $\begin{array}{c}\text { Mean } \\
\text { difference }\end{array}$ & DF & t-value & Eta squared \\
\hline $\mathbf{5 0}$ & $\mathbf{2 6 . 4 8}$ & $\mathbf{4 4 . 6 5}$ & $\mathbf{1 6 . 2 7}$ & $\mathbf{2 4}$ & $\mathbf{1 2 . 4 8}$ & $\mathbf{0 . 8 6}$ \\
\hline
\end{tabular}

Table(6) indicates that the treatment group achieved higher level of performance on the post speaking test than the pre-performance. To ensure the Active Learning Strategy on speaking skills of the treatment group, Eta squared formula was used. As shown in table(7) above, Eta squared value $(0.86)$ is more than 0.6 which means that the significance is high. T-value (12.48) is highly significant.

\section{Table(7)}

t-value of scores obtained in the pre-post performances of the nontreatment group in the Speaking test

\begin{tabular}{l|l|l|l|l|l|l|l}
\hline $\begin{array}{l}\text { Total } \\
\text { score }\end{array}$ & $\begin{array}{l}\text { No of } \\
\text { pupils }\end{array}$ & Pre & Post & $\begin{array}{l}\text { Mean } \\
\text { difference }\end{array}$ & DF & t-value & $\begin{array}{l}\text { Eta } \\
\text { squared }\end{array}$ \\
\hline 50 & 25 & 26.30 & 27.47 & 1.26 & 24 & 5.23 & 0.65 \\
\hline
\end{tabular}

*Significant at 0.01 level

Analysis of the obtained data using t-test in table(7) shows that non-treatment group achieved less degree of improvement on their speaking test. Eta squared value (0.5) is more than 0.1 and less than 0.6 which means that the significance is medium. 


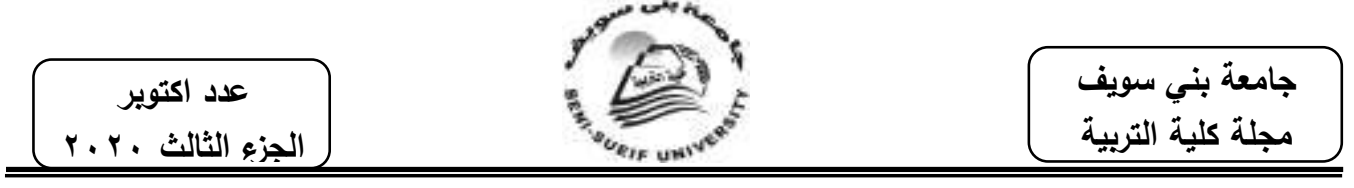

Table (8)

Comparison between the Treatment and the non-treatment group on the Speaking Skills Test

\begin{tabular}{c|c|c|c|c|c|c|c|c}
\hline Speaking test & $\begin{array}{c}\text { Total } \\
\text { score }\end{array}$ & Pre & Post & Mean & $\begin{array}{c}\text { Stander } \\
\text { Deviation }\end{array}$ & DF & $\begin{array}{c}\text { t- } \\
\text { value }\end{array}$ & $\begin{array}{c}\text { Eta } \\
\text { squared }\end{array}$ \\
\hline Treatment & $\mathbf{5 0}$ & $\mathbf{2 6 . 2 8}$ & $\mathbf{4 4 . 6 5}$ & $\mathbf{1 6 . 2 7}$ & $\mathbf{1 . 2 5}$ & $\mathbf{2 4}$ & $\mathbf{1 2 . 4 8}$ & $\mathbf{0 . 8 6}$ \\
\hline Non-treatment & $\mathbf{5 0}$ & $\mathbf{2 6 . 3 0}$ & $\mathbf{2 7 . 4 7}$ & $\mathbf{1 . 3 4}$ & $\mathbf{0 . 3 3}$ & $\mathbf{2 4}$ & $\mathbf{4 . 2 3}$ & $\mathbf{0 . 6 5}$ \\
\hline
\end{tabular}

The pre-testing of pupils on the speaking test was highly similar to both the non-treatment group (26.30) and the treatment group (26.20). The difference become higher within the treatment group, it reached (16.27) and become (1.34) within the non-treatment group, so the tvalue became (12.48) which indicates the acceptance of the second hypothesis.

\section{Recommendations}

In light of the results reached in the present study, a number of recommendations can be taken into consideration to help develop speaking skills of $3^{\text {rd }}$ graders:

- Developing pupils' awareness of the importance of using English as a means of communication inside the classroom.

- Encouraging the pupils' of drawing dialogues.

- Encouraging the pupils' use of negotiation strategies inside the classroom.

- Holding workshops for teachers to highlight the benefits of using active learning strategies in the classroom at the preparatory stage.

- Developing awareness of teachers and supervisors of the benefits of using active learning strategies in TEFL and how it is used at the preparatory stage.

- Holding workshops for teachers to highlight the benefits of using speaking inside the classroom at preparatory stage.

- Holding workshops for teachers to train them in how to teach speaking depending on modern strategies of teaching.

- Encouraging teachers to avoid using traditional teaching methods inside the classroom. 
عدد اكتوبر

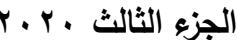

- Adapting "New Hello" course to be flexible and funny content including active learning strategy.

\section{Suggestions for further future research}

\section{It is suggested to study:}

- The effectiveness of active learning strategies in developing in drawing dialogues in English among the preparatory stage pupils.

- The effectiveness of using active learning strategies in developing in negotiation strategies in English among the preparatory stage pupils.

- The effectiveness of using replicating the present study to be implemented on a wide number of pupils and different grades.

- The effectiveness of using active learning strategies in developing reading and writing at preparatory stage.

- The effectiveness of using active learning strategies activities in classroom management.

- The effectiveness of using active learning strategies in reducing anxiety and increasing confidence.

- The effectiveness of using active learning strategies in developing pupil's attitudes towards EFL.

\section{Table of specifications of the Speaking Test}

\begin{tabular}{|c|c|c|c|c|}
\hline No & Behavioural Objectives & Test point & $\begin{array}{c}\text { Item } \\
\text { No }\end{array}$ & $\begin{array}{l}\text { Test of testing } \\
\text { items }\end{array}$ \\
\hline$*$ & $\begin{array}{c}\text { Answer questions using past } \\
\text { simple tense \& past } \\
\text { continuous tense }\end{array}$ & $\begin{array}{c}\text { answering questions using } \\
\text { past simple \& past } \\
\text { continuous tenses }\end{array}$ & & $\begin{array}{l}\text { Ask and } \\
\text { answer } \\
\text { questions }\end{array}$ \\
\hline$*$ & $\begin{array}{l}\text { Describe pictures using } \\
\text { learnt vocabulary }\end{array}$ & $\begin{array}{c}\text { identifying pictures of } \\
\text { new vocabulary }\end{array}$ & & $\begin{array}{l}\text { Ask and } \\
\text { answer } \\
\text { questions }\end{array}$ \\
\hline$*$ & $\begin{array}{l}\text { Answer questions using } \\
\text { length of statements }\end{array}$ & _answering questions & & $\begin{array}{l}\text { Ask and } \\
\text { answer } \\
\text { questions }\end{array}$ \\
\hline$*$ & $\begin{array}{l}\text { Use adjectives \& adverbs of } \\
\text { manner }\end{array}$ & $\begin{array}{l}\text { using grammatical } \\
\text { structure }\end{array}$ & & $\begin{array}{c}\text { Picture } \\
\text { description }\end{array}$ \\
\hline$*$ & $\begin{array}{l}\text { Use learnt vocabulary in } \\
\text { describing pictures of } \\
\text { activities \& musical } \\
\text { instruments }\end{array}$ & _using learnt vocabulary & & $\begin{array}{c}\text { Picture } \\
\text { description }\end{array}$ \\
\hline$*$ & $\begin{array}{l}\text { Pronounce the sounds:/s/ in } \\
\text { "cymbals", /k/ in }\end{array}$ & $\begin{array}{l}\text { _pronouncing the sounds: } \\
\text { /k/ in 'perfect", / } / \mathrm{S} \text { / in }\end{array}$ & & $\begin{array}{c}\text { Picture } \\
\text { description }\end{array}$ \\
\hline
\end{tabular}




\begin{tabular}{|c|c|c|c|c|}
\hline 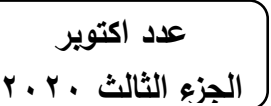 & الجزء الثالث & \multirow[b]{2}{*}{ Test point } & \multicolumn{2}{|c|}{ جامعة بني سويف } \\
\hline No & Behavioural Objectives & & $\begin{array}{c}\text { Item } \\
\text { No }\end{array}$ & $\begin{array}{l}\text { Test of testing } \\
\text { items }\end{array}$ \\
\hline & $\begin{array}{l}\text { '"perfect', /S/ in } \\
\text { "'should"',/silent h/ in } \\
\text { 'Where", }\end{array}$ & $\begin{array}{l}\text { "should",,/silent h/ in } \\
\text { "'Where", }\end{array}$ & & \\
\hline$*$ & $\begin{array}{c}\text { Talk about a visit to New } \\
\text { York City }\end{array}$ & $\begin{array}{c}\text { _talking about a visit to } \\
\text { New York City }\end{array}$ & & $\begin{array}{c}\text { Picture } \\
\text { description }\end{array}$ \\
\hline$*$ & $\begin{array}{l}\text { Pronounce the sounds:/z/ in } \\
\text { "xylophone", ,/f/ in } \\
\text { "'enough", }\end{array}$ & _pronouncing sounds & & $\begin{array}{l}\text { Ask and } \\
\text { answer } \\
\text { questions }\end{array}$ \\
\hline$*$ & $\begin{array}{c}\text { Ask each other about } \\
\text { adverbs of manner of } \\
\text { musical instruments "'How' } \\
\text { \& When', }\end{array}$ & 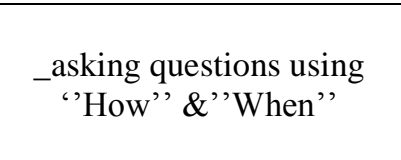 & & $\begin{array}{l}\text { Ask and } \\
\text { answer } \\
\text { questions }\end{array}$ \\
\hline$*$ & $\begin{array}{l}\text { Use learnt vocabulary in } \\
\text { constructing mini-dialogues } \\
\text { about activities in } \\
\text { kindergarten \& actions at } \\
\text { school }\end{array}$ & _using learnt vocabulary & & $\begin{array}{l}\text { Ask and } \\
\text { answer } \\
\text { questions }\end{array}$ \\
\hline$*$ & $\begin{array}{c}\text { Present a dialogue at the } \\
\text { airport }\end{array}$ & _presenting a dialogue & & $\begin{array}{l}\text { Constructing } \\
\text { mini dialogue }\end{array}$ \\
\hline$*$ & $\begin{array}{c}\text { Practice making an } \\
\text { emergency telephone call }\end{array}$ & _using learnt vocabulary & & $\begin{array}{l}\text { Constructing } \\
\text { mini dialogue }\end{array}$ \\
\hline$*$ & $\begin{array}{l}\text { Use correct grammatical } \\
\text { structures in presenting a } \\
\text { dialogue }\end{array}$ & $\begin{array}{l}\text { _using correct grammatical } \\
\text { structures }\end{array}$ & & $\begin{array}{l}\text { Constructing } \\
\text { mini dialogue }\end{array}$ \\
\hline$*$ & $\begin{array}{l}\text { Form a variety of questions } \\
\text { in different tenses }\end{array}$ & _forming questions & & $\begin{array}{c}\text { Asking } \\
\text { questions }\end{array}$ \\
\hline$*$ & $\begin{array}{l}\text { Talk about past simple\& } \\
\text { past continuous }\end{array}$ & $\begin{array}{c}\text { _using grammatical } \\
\text { structure }\end{array}$ & & $\begin{array}{c}\text { Picture } \\
\text { description }\end{array}$ \\
\hline$*$ & $\begin{array}{l}\text { Talk about past ability \& } \\
\text { inability }\end{array}$ & $\begin{array}{c}\text { talking about ability \& } \\
\text { inability }\end{array}$ & & $\begin{array}{l}\text { Open ended } \\
\text { questions }\end{array}$ \\
\hline
\end{tabular}


عدد اكتوبر

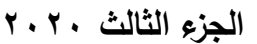

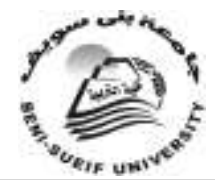

\section{جامعة بني سويف كإية لإنربة \\ مجلة كلية التربية}

\section{References}

Abbot,C. and Godinho, S.(2011) "Thinking Voices: Developing oral communication skills". Online Available at: http//books.googalscholar.com Atas, M.(2015) "'The reduction of speaking anxiety in EFL learners through learning circles' Procedia-Social and Behavioral Sciences vol176, Pp.961-969.

Baily, M.(2012). "'Issues in Teaching Speaking Skills to adult ESOL learners.' 'ERIC, P.35. from http:llericanetldbledolEd

Bahrain, T(2012) 'How to Teach Speaking Skill?', Journal of Education and Practice, Vol. 3,No. 2, Pp.25-29.

Boonkit, K.(2010)' 'Enhancing the development of speaking skills for non-native speakers of English', Procedia- Social and Behavioral Sciences, Vol.2,Issue2, Pp.1305-1309.

Boyle,J.(2010) "Benefits to active learning"'Online available at http://theapple.monster.com

Bulter,S (2011). Active learning strategies to promote critical thinking. Journal of Athletic Training, 38(3), 263-267.

David and Alexander(2011) "How to speak English More Accurately" Online Available at http//musicalenglishlessons.com

Fink,L.D.(2009). Active Learning . University of Oklahoma. Instructional Development Program.

Firlik.J(2012) "What is Active Learning and why it is Important?" Online Available at www.gwu.edu/eriche.

Folse,K., and Ivone,J.(2015)"More Discussions Starters Activities for Speaking Fluency"' Micgigan, The University of Micgigan Press.

Huntly,H.(2016)English Language Evaluation Program."Tijuana,Mexico.

Johnson and smith(2019). The Practice of English Language Teaching. England Pearson Education Limited.

Mc Fadden (2010) Using Brainstorming in TEFL. Online available at http://pearsonclassroomlink.com

Morozova, Y. (2013) "Methods of Enhancing Speaking Skills of Elementary Level Students."Translation Journal, Vol. 17, No. 1.

Sagban, P.(2015) "Role Playing Simulation techniques" online available at http://iteslj.org.

Smith, C. (2013). "Skills Students use when Speaking and Listening." Eric clearing house on Reading. English and communication Bloomington, IN. ERIC Number: ED480895

Torky,S(2016). The Effectiveness of a task Based Instruction program Developing the English Language Skills of Secondary PhD Ain Shams university, Woman's college. 
Wei, I. (2018). "Teaching Listening in EFL Classroom in Senior High Schools in Taiwan" .Available at:http://english.tyhs.edu.tw/xoops/html/tyhs/teachsource101/06plan.pd

Windle, $R$ and Warren,S(2011)."Communication skills"Available at: http://www.directionservice.org/cadre/section4.cfm 
عدد اكتوير

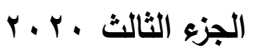

تهدف الدراسة الحاليه الي معرفة اثر أستخدام بعض استراتيجيات التعلم النشط في تتمية المهارات الثفهية للغة الانجليزية واثرها علي دوافعهم. أعتمدت الدراسة علي المنهج الثنبه

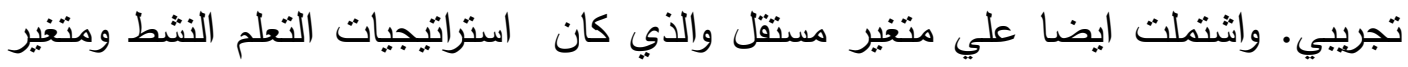

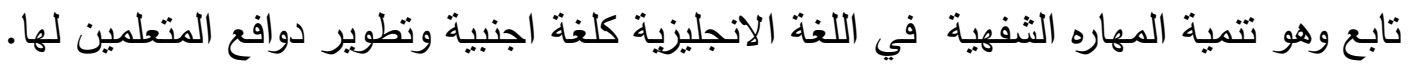

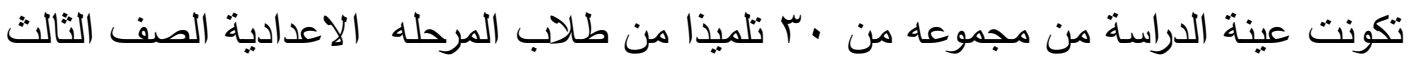

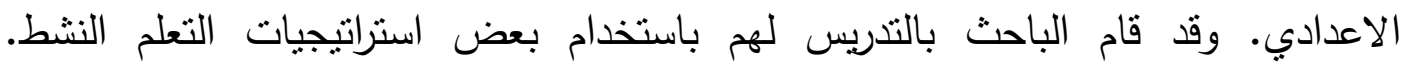

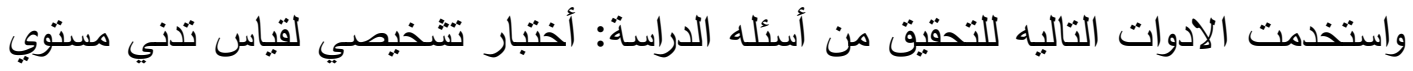
تعلم الطلاب لمهارة الاستحدث في اللغة الانجليزية، أختبار قبلي بعدي في مفردات اللغة الأنة

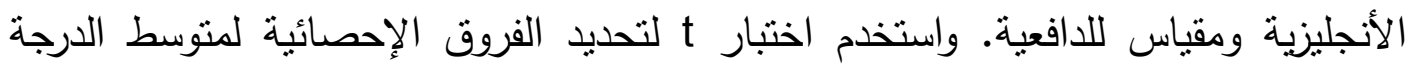

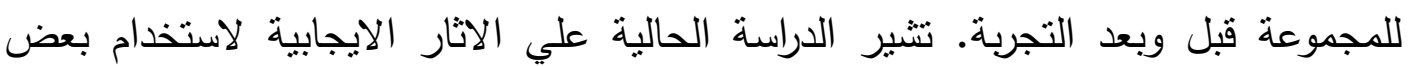

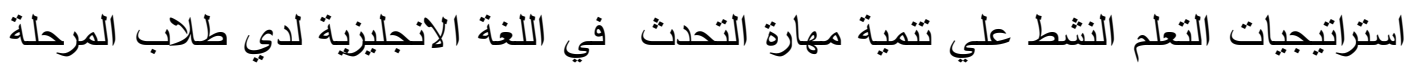

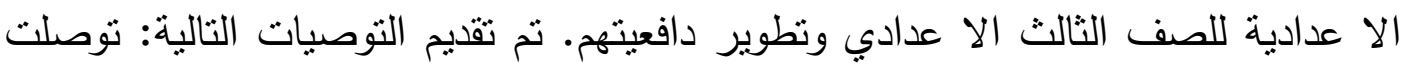

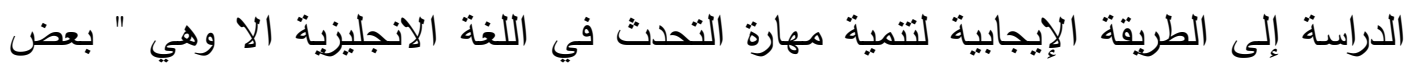

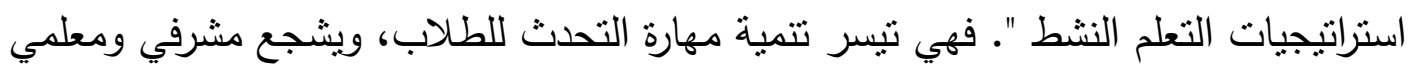
اللغة الإنجليزية على استخدام الإستراتيجية الحالية في التدريس التي تجعل التلاميذ يشاركون

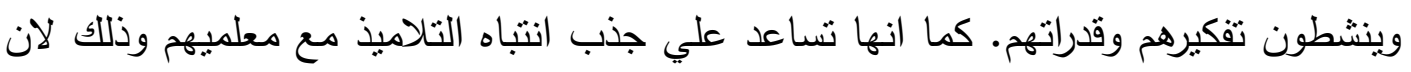

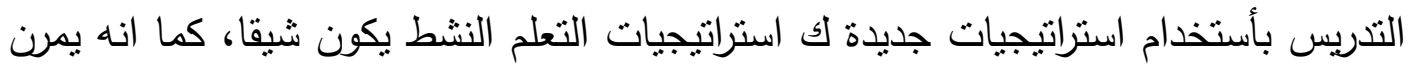

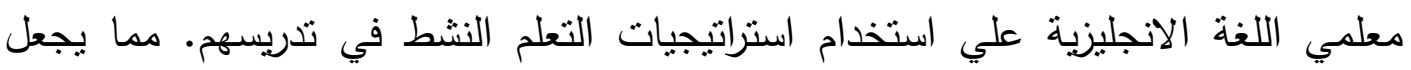
المعلمون يستخدمون طرق تدريس حديثة والتي تقلل من جهد المعلمين، وتجعلهم موجهين ومرشدين لطلابهم، وتجعل الطلاب متفاعلين ومشاركين داخل الفصل وبعزز استخدام استراتيجيات التعلم النشط في تدريس كل الوحدات في جميع المراحل التعليمية.

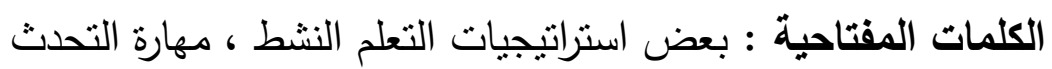

